\title{
Australian Journal of Crop Science
}

\section{Selectivity of herbicides in the post-emergence sugarcane seedlings in primary selection fields}

\author{
Tácio Peres Silva*1, Amanda Mendes de Moura ${ }^{1}$, Bruno Manoel Rezende de Melo ${ }^{2}$, Douglas Goulart \\ Castro ${ }^{1}$, Laís Moretti Tomé ${ }^{1}$, Marco Renan Félix ${ }^{1}$, Flávia Barbosa Silva Botelho ${ }^{1}$
}

\author{
${ }^{1}$ University Federal of Lavras (UFLA), University Camps, Mailbox 3037, CEP 37200-000, Lavras, Minas Gerais, Brazil \\ ${ }^{2}$ Federal Institute of Education, Science and Technology of South of Minas Gerais (IFSULDEMINAS), Inconfidentes \\ Camps, Inconfidentes, CEP 37576-000, Minas Gerais, Brazil
}

\section{*Corresponding author: tacioagro@gmail.com}

\section{Abstract}

The hypothesis here proposed is that, in primary fields of mass selection $\left(F_{1}\right)$ of sugarcane, herbicides exert a selective action when applied in the early post-emergence of seedlings (POST ${ }_{-i}$ ) and supplemented after their establishment phase (POST $\left.T_{-1}\right)$ even in sandy soils. To verify such hypothesis, the selectivity of herbicides was studied on seedlings of three sugarcane families, after their application both at early and late post-emergence in primary selection fields (F1). The field had a randomized blocks design, with five replications, and the subdivided plots scheme was used. Twelve herbicide treatments were allocated in the plots $\left(27 \mathrm{~m}^{-2}\right)$, whereas the sub-plots $\left(9 \mathrm{~m}^{-2}\right)$ contained three families of seedlings. Each sub-plot consisted of a transplanted row $(0.5 \times 1.50 \mathrm{~m})$

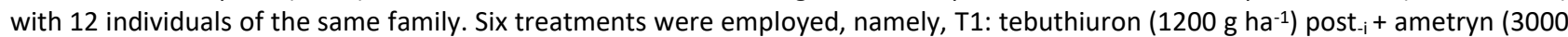
$\mathrm{g} \mathrm{ha}^{-1}$ ) post.

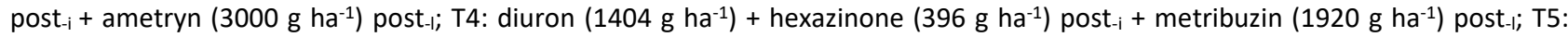
sulfentrazone $\left(800 \mathrm{~g} \mathrm{ha}^{-1}\right)$ post $_{-i}+$ metribuzin $\left(1920 \mathrm{~g} \mathrm{ha}^{-1}\right)$ post-, and T6: weeded plot. The sugarcane families were: F400 ( IAC086155 x unknown), F43 ( + IACBIO264 $\times$ IAC911099), and F14 ( IACSP991305 $\times$ GlagaH). We concluded that the herbicides tebuthiuron (1200 $\left.\mathrm{g} \mathrm{ha}^{-1}\right)$, diuron $\left(104 \mathrm{~g} \mathrm{ha}^{-1}\right)+$ hexazinone $\left(396 \mathrm{~g} \mathrm{ha}^{-1}\right)$, or sulfentrazone $\left(800 \mathrm{~g} \mathrm{ha}^{-1}\right)$, when applied in the early post-emergence and supplemented with ametryn $\left(3000 \mathrm{~g} \mathrm{ha}^{-1}\right)$ or metribuzin $\left(1920 \mathrm{~g} \mathrm{ha}^{-1}\right)$ in late post-emergence (60 days from planting) of the sugarcane families studied, were selective to the seedlings. That is, no toxicity symptoms with a potential to impede the final selection of seedlings occurred.

Keywords: Saccharum spp., weeds, phytotoxicity, breeding.

\section{Introduction}

In commercial areas of sugarcane production, the interference of weed reduces the productivity from $23 \%$ (Richard et al., 2007) to $46 \%$ (Silva et al., 2009). In experimental fields of crop genetic improvement, particularly in primary fields of mass selection (F1), which are characterized by the transplantation of seedlings, the presence of weeds can cause a total disposal of individuals. However, it is desirable that the chemical management does not cause prolonged intoxication symptoms in seedlings, so to facilitate their selection by breeders, which, according to Skinner et al. (1982), is based on the visual aspect of plants. Symptoms caused by herbicides, such as chlorosis and necrosis (Dayan et al., 2009), can be confused with symptoms of scald (Xanthomonas albilineans) and rust (Puccinia melanocephala), constituting a factor for seedling elimination in the selection process.

Trying to mitigate injuries in the sugarcane leaves, breeders opt for applying tebuthiuron because, according to Soares et al. (2011), it provides light and short-duration chlorosis in the crop leaves. Its selectivity was also observed in the commercial cultivars RB835089 (Azania et al. 2001) and RB855113 (Negrisoli et al. 2004).

The tebuthiuron is applied in the pre-emergence of weeds, being and is ineffective over Cynodon dactylon and Cyperus rotundus, which are also present in the crop agroecosystem. In this case, the application of other herbicides is recommended for commercial sugarcane fields, preferably preplant-incorporated (PPI) such as imazapyr and imazapic (MAPA, 2015).

Nevertheless, the application of herbicide in sandy soils may cause severe intoxication symptoms. The herbicide sorption dynamics is deficient in soils with lower availability of colloids (clay and organic matter); hence, substantial amounts of herbicide may remain in the soil solution and damage the plants when absorbed (Pusino et al., 1997). 
Table 1. Herbicide treatments proposed for primary fields of seedling selection (F1) in sugarcane. Agronomic Institute of Campinas (IAC), 2015.

\begin{tabular}{|c|c|c|c|c|c|}
\hline \multirow[b]{2}{*}{ T1 } & POST-i & $\left(\mathrm{g} \mathrm{ha}^{-1}\right)$ & \multirow[b]{2}{*}{+} & \multirow{2}{*}{$\frac{\mathrm{POST}_{-1} *}{\text { ametryn }}$} & $\left(\mathrm{g} \mathrm{ha}^{-1}\right)$ \\
\hline & tebuthiuron & 1200 & & & 3000 \\
\hline \multirow{2}{*}{$\mathrm{T} 2$} & diuron & 1404 & \multirow{2}{*}{+} & \multirow{2}{*}{ ametryn } & \multirow{2}{*}{3000} \\
\hline & hexazinone & 396 & & & \\
\hline T3 & sulfentrazone & 800 & + & ametryn & 3000 \\
\hline \multirow{2}{*}{$\mathrm{T} 4$} & diuron & 1404 & \multirow{2}{*}{+} & \multirow{2}{*}{ metribuzin } & \multirow{2}{*}{1920} \\
\hline & hexazinone & 396 & & & \\
\hline T5 & sulfentrazone & 800 & + & metribuzin & 1920 \\
\hline T6 & weeded plot & -- & -- & capina & -- \\
\hline
\end{tabular}

Early post-emergence (POST-i); late post-emergence (POST $)$; -- absence of herbicides; ${ }^{*} 0.5 \%$ of the total mineral oil volume.

Table 2. Symptoms of intoxication (\%) and chlorophyll content (spad) in the three families of sugarcane seedlings grown in primary fields of mass selection (F1). Agronomic Institute of Campinas (IAC), 2015.

\begin{tabular}{|c|c|c|c|c|c|c|}
\hline \multirow[t]{2}{*}{ Treatment } & \multicolumn{3}{|c|}{$\begin{array}{l}120 \text { DAApost }_{i} \\
\text { Symptoms of intoxication (\%) } \\
\text { Families }\end{array}$} & \multicolumn{3}{|c|}{ Chlorophyll content (SPAD) } \\
\hline & 400 & 14 & 43 & 400 & 14 & 43 \\
\hline $\begin{array}{l}\text { T1-tebuthiuron }{ }^{1} \\
\text { ametryn }^{2}\end{array}$ & $12.83 \mathrm{ab}$ & $4.67 \mathrm{a}$ & $16.34 \mathrm{bc}$ & 39.12 a & $40.43 a b c$ & $40.05 \mathrm{a}$ \\
\hline $\begin{array}{l}\text { T2- diuron }{ }^{1} \\
\text { hexazinone } \\
\text { ametryn }^{2}\end{array}$ & $20.14 \mathrm{a}$ & $3.33 \mathrm{a}$ & $30.67 \mathrm{ab}$ & 36.98 a & $40.33 a b c$ & $35.73 \mathrm{a}$ \\
\hline $\begin{array}{l}\text { T3-sulfentrazone } \\
\text { ametryn }^{2} \\
\text { T4-diuron }\end{array}$ & $16.67 \mathrm{ab}$ & $0.00 \mathrm{a}$ & $23.00 \mathrm{abc}$ & 38.64 a & $42.23 \mathrm{ab}$ & 38.83 a \\
\hline $\begin{array}{l}\text { hexazinone }{ }^{1} \\
\text { metribuzin }^{2}\end{array}$ & $16.00 \mathrm{ab}$ & $1.67 \mathrm{a}$ & $35.50 \mathrm{a}$ & $38.90 \mathrm{a}$ & $42.45 a b$ & $33.88 \mathrm{a}$ \\
\hline $\begin{array}{l}\text { T5-sulfentrazone }{ }^{1} \\
\text { metribuzin }^{2}\end{array}$ & $5.33 \mathrm{bc}$ & $0.00 \mathrm{a}$ & $13.83 \mathrm{c}$ & $43.64 \mathrm{a}$ & $42.89 \mathrm{a}$ & $42.34 \mathrm{a}$ \\
\hline T6-weeded plot & $0.00 \mathrm{c}$ & $0.00 \mathrm{a}$ & $0.00 \mathrm{~d}$ & 35.27 a & $35.37 \mathrm{abcd}$ & $34.70 \mathrm{a}$ \\
\hline dms (LSD p<0.05) & 20.20 & 21.77 & 21.88 & 10.32 & 10.47 & 11.17 \\
\hline CV (\%) & 14.70 & 18.93 & 12.05 & 12.26 & 7.56 & 14.68 \\
\hline$(p>F)$ & $<0.0001$ & $<0.0001$ & $<0.0001$ & $<0.0001$ & 0.0170 & $<0.0001$ \\
\hline
\end{tabular}

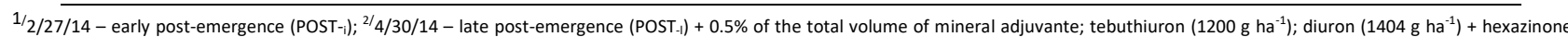
$\left(396 \mathrm{~g} \mathrm{ha}^{-1}\right)$; sulfentrazone $\left(800 \mathrm{~g} \mathrm{ha}^{-1}\right)$; ametryn $\left(3000 \mathrm{~g} \mathrm{ha}^{-1}\right)$; metribuzin $\left(1920 \mathrm{~g} \mathrm{ha}^{-1}\right)$.

Table 3. Living plants (\%) and selected plants of the three families of sugarcane seedlings grown in primary fields of mass selection (F1). Agronomic Institute of Campinas (IAC), 2015

\begin{tabular}{|c|c|c|c|c|c|c|}
\hline \multirow{3}{*}{ Treatment } & \multicolumn{6}{|c|}{240 DAApost $_{\mathrm{i}}$} \\
\hline & Families & & & & & \\
\hline & 400 & 14 & 43 & 400 & 14 & 43 \\
\hline $\begin{array}{l}\text { T1-tebuthiuron }{ }^{1} \\
\text { ametryn }^{2}\end{array}$ & $91.80 \mathrm{a}$ & $90.20 \mathrm{a}$ & $88.60 \mathrm{a}$ & $0.00 \mathrm{~b}$ & $5.00 \mathrm{ab}$ & $3.40 \mathrm{a}$ \\
\hline \multicolumn{7}{|l|}{ T2- diuron ${ }^{1}$} \\
\hline $\begin{array}{l}\text { hexazinone } \\
\text { ametryn }^{2}\end{array}$ & $81.80 \mathrm{a}$ & $83.40 \mathrm{ab}$ & $96.80 \mathrm{a}$ & $3.60 a b$ & $8.40 \mathrm{a}$ & $0.00 \mathrm{~b}$ \\
\hline $\begin{array}{l}\text { T3-sulfentrazone } \\
\text { ametryn }^{2}\end{array}$ & $88.40 \mathrm{a}$ & $90.20 \mathrm{a}$ & $80.00 \mathrm{a}$ & $0.00 \mathrm{~b}$ & $1.60 a b$ & $0.00 \mathrm{~b}$ \\
\hline \multicolumn{7}{|l|}{ T4-diuron ${ }^{1}$} \\
\hline $\begin{array}{l}\text { hexazinone }^{1} \\
\text { metribuzin }^{2}\end{array}$ & $96.80 \mathrm{a}$ & $78.40 \mathrm{ab}$ & $86.80 \mathrm{a}$ & $3.40 \mathrm{ab}$ & $5.00 a b$ & $0.00 \mathrm{~b}$ \\
\hline $\begin{array}{l}\text { T5-sulfentrazone } \\
\text { metribuzin }^{2}\end{array}$ & $85.00 \mathrm{a}$ & $90.20 \mathrm{a}$ & $95.00 \mathrm{a}$ & $1.60 a b$ & $3.40 \mathrm{ab}$ & $1.60 \mathrm{ab}$ \\
\hline T6-weeded plot & 83.20 a & $81.80 \mathrm{ab}$ & $75.00 \mathrm{a}$ & $0.00 \mathrm{~b}$ & $3.20 a b$ & $0.00 \mathrm{~b}$ \\
\hline dms (LSD p<0.05) & 28.93 & 26.39 & 27.43 & 5.01 & 7.20 & 3.11 \\
\hline CV (\%) & 20.70 & 13.13 & 14.44 & 20.58 & 27.98 & 13.93 \\
\hline$(p>F)$ & $<0.0003$ & $<0.0001$ & $<0.0001$ & 0.3775 & $<0.0001$ & 0.5491 \\
\hline
\end{tabular}


The alternative management of areas infested by $C$. rotundus is the use of sulfentrazone (MAPA, 2015). However, when applied in the early post-emergence of seedlings, this herbicide can cause symptoms of intoxication in the leaves and hinder their selection.

Another gap left by the use of tebuthiuron is the postemergence (POST) management, as this herbicide is only effective when applied in the pre-emergence of weeds (MAPA, 2015). In commercial sugarcane fields, such gap may be filled by diuron + hexazinone (Monquero, 2007), metribuzin (Parreira et al., 2012) and ametryn (Negrisoli et al., 2004), among others.

As a complement to the use of tebuthiuron in F1 fields, we propose here the hypothesis that, in primary fields of mass selection (F1) of sugarcane, herbicides exert a selective action when applied in the early post-emergence of seedlings (POST - ) and supplemented after their establishment phase (POST 1 ), even in sandy soils. To check such hypothesis, this study aimed at analyzing the selectivity of herbicides on seedlings of three families of sugarcane, after their application in the early and late post-emergence in primary selection fields (F1).

\section{Materials and methods}

\section{Origin of the plants}

Initially, the seeds of F43 (FIACBIO264 x IAC911099) and F14 ( IACSP991305 $x$ GlagaH) sugarcane families were obtained by biparental crossing, and the F400 family ( IAC086155 x unknown), through the polycross method. The seeds were placed in greenhouses for germination and, after 60 days, the seedlings (individuals) were 10- to $15-\mathrm{cm}$ height and ready for transplantation in the primary fields of mass selection (F1).

\section{Experiment location and characteristics}

The experimental field was located in Jaú, São Paulo, Brazil ( $22^{\circ} 17^{\prime} 47^{\prime \prime}$ South Latitude and $48^{\circ} 33^{\prime} 31^{\prime \prime}$ West Longitude), characterized by a high-altitude tropical climate (Cwa), a dystroferric red latosol, sandy texture $(278,619$ and $103 \mathrm{~g}$ $\mathrm{kg}^{-1}$ of clay, sand and silt), $\mathrm{pH} 4.6,22 \mathrm{~g} \mathrm{dm}^{-3}$ of organic matter, $69.16 \mathrm{mmol}_{\mathrm{c}} \mathrm{dm}^{-3}$ of CTC, $9 \mathrm{mg} \mathrm{dm}^{-3}$ of $P_{\text {resin, }}$ and 2.46, 26.32 and $7.38 \mathrm{mmol}_{\mathrm{c}} \mathrm{dm}^{-3}$ of $\mathrm{K}, \mathrm{Ca}$ and $\mathrm{Mg}$, respectively.

\section{Installing the experiment}

Initially $(02 / 15 / 14)$, the desiccation of the ratoons and remaining weeds was made with glyphosate (2160 $\left.\mathrm{g} \mathrm{ha}^{-1}\right)$, using a trailed sprayer with TT110/02 nozzle tips and a spray volume of $200 \mathrm{~L} \mathrm{ha}^{-1}$. Subsequently, the soil was prepared with heavy and light grids, with no application of limestone or gypsum. Then, the experiment was delimited in a randomized block design with 12 treatments, with split subplots and in five replications. The herbicide treatments were allocated in the plots ( 3 rows $\times 6 \mathrm{~m} \times 1.5 \mathrm{~m}$ ) (Table 1 ), and seedlings were placed on the sub-plots ( 1 row $\times 6 \mathrm{~m} \times 1.5 \mathrm{~m}$ ). For each sub-plot, were transplanted 12 individuals of the same family, spaced from each other by $0.50 \mathrm{~m}$.

Seedlings were mechanically transplanted $(02 / 20 / 14)$ with a space of $1.5 \mathrm{~m}$ between rows and $0.5 \mathrm{~m}$ between plants. At the same time, $1200 \mathrm{~kg} \mathrm{ha}^{-1}$ of the $4-14-8$ formulation were distributed along the planting line.

The experiment was irrigated to ensure the establishment of plants and the herbicides were applied to the plots $(02 / 27 / 2014)$ in the early post-emergence (POST $-i)$ of seedlings, as shown in Table 1 . The application occurred between 7:48 and 9:00 a.m., period in which the air temperature was around 25.3 to $32^{\circ} \mathrm{C}$, with $75-62 \%$ relative humidity, $30 \%$ cloudiness, and winds from 2.8 to $6 \mathrm{~km} \mathrm{~h}^{-1}$.

After 61 days, herbicides were applied (04/30/14) in the late post-emergence (POST 1 ), thus completing the six proposed managements (Table 1). For such applications, a constant pressure knapsack sprayer (CO2) was used, with a flow of 240 L ha-1. The application occurred between 8:24 and 9:05 a.m., with 18.7 to $22.8^{\circ} \mathrm{C}$ air temperature, 65.4 to $55.6 \%$ relative humidity, $50 \%$ cloudiness, and winds from 2.5 to 5 $\mathrm{km} \mathrm{h}^{-1}$.

\section{Assessments conducted}

Due to the genetic variability of the 1080 individuals under analysis, the same variables used in the seedling selection process in $\mathrm{F} 1$ fields were assessed. At 120 DAApost-i, each seedling was evaluated for intoxication symptoms and chlorophyll content and, at 240 DAApost-i, the percentage of live and selected individuals was also verified. Injuries were measured by percentage, with the visual scale ranging from $0 \%$ (no injuries) to $100 \%$ (plant death). The chlorophyll content was obtained by chlorophyll meter readings (SPAD502 Plus, Konica Minolta) performed in two random spots of the leaves.

The percentage of living seedlings was obtained by the equation $(($ notes $/ 12) * 100)$, in which we considered the following scores: 1 for living plants, 0 for dead plants, and 12 for the total number of seedlings per subtransplanted portion. For the percentage of selected seedlings, equation (Eselected seedlings/12)*100 was used, whereas the sum considered the number of plants able for future selection (F2). Were regarded as selected the plants without diseases, with proper culm diameter and tillering for commercial harvesting, and whose Brix juice percentage was higher than $10 \%$.

\section{Statistical analysis}

According to the proposed design, variables were submitted to the $F$ test for variance analysis and the treatment averages were compared with the LSD test $(p<0.05)$, using the SAS statistical software.

\section{Results and Discussion}

Herbicides applied in the post-emergence of seedlings were certainly absorbed by the leaves and roots. In the leaves, the association between the lipophilicity (kow) of molecules (from 9.8 for sulfentrazone to 589 for diuron) and the adjuvant used favored the herbicide dynamic on the leaf surface, facilitating its absorption.

In the soil, regardless of each molecule solubility (42 for diuron and 33,000 ppm for hexazinone), the $439.6 \mathrm{~mm}$ of rainfall that occurred during the trial period favored the herbicide application. Concomitantly with the movement of molecules, according to Rigi et al. (2015), the sorption 
process is possibly not impaired when the herbicides have a moderate koc ( 43 for sulfentrazone and 480 for diuron). However, the smaller amount of colloids $\left(619 \mathrm{~g} \mathrm{~kg}^{-1}\right.$ of sand and $22 \mathrm{~g} \mathrm{dm}^{-3}$ of organic matter) favored the herbicides permanence in the soil solution (Prata and Lavorenti, 2000), facilitating its absorption by the seedlings.

Nonetheless, among the constituent variables of herbicide dynamics in the soil, the light sandy texture was not enough to discourage the selectivity of herbicides. At 120 DAA $A_{\text {post-1, }}$ the intoxication symptoms observed in the seedlings (Table 2) were mild and characteristic of chlorosis. The most intense symptoms did not exceed $20.14 \%$ ( $T 2$ in $\mathrm{F} 400$ ), $4.67 \%$ ( $\mathrm{T} 1$ in $\mathrm{F} 14$ ), and $35.50 \%$ (T3 in F43).

In commercial cultivars, similar injuries were also observed after the application of herbicides in sugarcane ratoons. Injuries up to $25 \%$ were observed in a clayey soil by Schiavetto et al. (2012), due to the use of metribuzin (1920 g $\left.\mathrm{ha}^{-1}\right)+$ diuron $\left(842 \mathrm{~g} \mathrm{ha}^{-1}\right)+$ hexazinona $\left(238 \mathrm{~g} \mathrm{ha}^{-1}\right)$, and by Zera et al. (2011) when applying ametryn (1463 $\left.\mathrm{g} \mathrm{ha}^{-1}\right)+$ trifloxysulfuron-sodium ( $\left.37 \mathrm{~g} \mathrm{ha}^{-1}\right)$.

Similarly as with the injuries, the chlorophyll content was not harmed by the herbicides (Table 2). For each family, from T1 to T6, were provided contents close to those obtained in the standard treatment ( $\mathrm{T} 1 \mathrm{:} 39.12$ to $\mathrm{F} 400,40.43$ to $\mathrm{F} 14$, and 40.05 to F43) and in the weeded plot (T6: 35.37 to F400, 35.27 to $F 14$, and 34.70 to F43), even after ametryn and metribuzin were applied in the POST -.. $_{\text {. }}$.

Both herbicides inhibit the electron transport between photosystems within the photosynthesis process (Dayan and Zaccaro, 2012) and, thus, the most present symptom is the yellowing. In commercial sugarcane areas, similar symptoms were also observed by Souza et al. (2009) and Schiavetto et al. (2012).

Naturally, the death of plants in fields of mass selection, regardless of the herbicide treatment used, is commonly observed (Table 3). This can be verified by the percentage of living seedlings in the treatment plot (T6), in the plants of F400 (83.20\%), F14 (81.80\%) and F43 (75\%). However, the survival of 81.80 (T2) to $91.80 \%$ (T1) in F400, 78.40 (T4) to $90.20 \%$ (T1, T3, and T5) in F14, and 86.80 (T4) to $96.80 \%$ (T2) in F43 at primary fields of mass selection is fully acceptable in practice.

The high percentage of living seedlings (Table 3) shows that these treatments can be used in primary fields (F1) without significant damage to the seedlings evaluated. Treatments with sulfentrazone (T3 and T5), indicated for control of Cyperus rotundus and Ipomea spp, or treatments with diuron + hexazinone for broadleaf species and Ipomoea spp. (MAPA 2015), were selective to the seedlings and stood out as an alternative to the standard treatment with tebuthiuron (T1). At the 240 DAA $_{\text {post-i }}(10 / 21 / 14)$, it was possible to select up to $3.60 \%$ seedlings in $\mathrm{F} 400$ (T2), up to $8.40 \%$ in F14 (T2) and $3.40 \%$ in F43 (T1) (Table 3). Hence, alternatives (T2 to T5) to the standard treatment with tebuthiuron + ametryn (T1) were selective, as they did not affect the development of plants and allowed the final selection of the progenies by breeders.

\section{Conclusion}

The herbicides tebuthiuron (1200 $\left.\mathrm{g} \mathrm{ha}^{-1}\right)$, diuron (104 $\left.\mathrm{g} \mathrm{ha}^{-1}\right)$ + hexazinone (396 $\left.\mathrm{g} \mathrm{ha}^{-1}\right)$, or sulfentrazone (800 $\left.\mathrm{g} \mathrm{ha}^{-1}\right)$, when applied in early post-emergence and complemented with ametryn ( $\left.3000 \mathrm{~g} \mathrm{ha}^{-1}\right)$ or metribuzin $\left(1920 \mathrm{~g} \mathrm{ha}^{-1}\right)$ in late post-emergence (60 days after planting) of the $F 400$ (IAC086155 x unknown), F43 (IACBIO264 x IAC911099) , and F14 ( ${ }^{\circ}$ IACSP991305 $\times{ }^{\text {G }}$ GlagaH) families, were selective to the seedlings. No symptoms of intoxication with the potential to hinder the final selection of seedlings were observed.

\section{References}

Azania CAM, Casagrande AA, Rolim JC (2001) Seletividade de imazapic às soqueiras de cana-de-açúcar (Saccharum spp.). Planta Daninha. 19(3):345-350.

Dayan FE, Trindade MLB, Velini ED (2009) Amicarbazone, a New Photosystem II Inhibitor. Weed Sci. 57(6):579-583.

Dayan FE, Zaccaro MLM (2012) Chlorophyll fluorescence as a marker for herbicide mechanisms of action. Pesticide Biochemistry and Physiology. 102:189-197.

MAPA. Ministério da Agricultura, Pecuária e Abastecimento. 2015. Agrofit $<$ http://extranet,agricultura,gov,br/agrofit_cons/principal_agrofit _cons>.

Monquero PA, Amaral LR, Silva AC, Silva PV, Binha DP (2007) Eficácia de herbicidas em diferentes quantidades de palha de cana-de-açúcar no controle de Euphorbia heterophylla. Planta Daninha. 25(3):613-619.

Negrisoli E, Velini ED, Tofoli GR, Cavenaghi AL, Martins D, Morelli JL, Costa AGF (2004) Seletividade de herbicidas aplicados em préemergência na cultura de cana-de-açúcar tratada com nematicidas. Planta Daninha. 22(4):567-575.

Parreira MC, Cardozo NP, Pereira FCM, Alves PLCA (2012) Superação de dormência das sementes e controle químico de Momordica charantia L. Bioscience J. 28(3):358-365.

Prata F, Lavorenti A (2000) Comportamento de herbicidas no solo: influência da matéria orgânica. Rev Biociências. 6(2):17-22.

Pusino A, Petretto S, Gessa C (1997) Adsorption and desorption of imazapyr by soil. J Agricu Food Chem. 45(3):1012-1016.

Rigi MR, Farahbakhsh M, Rezaei K (2015) Adsorption and desorption behavior of herbicide metribuzin in different soils of Iran. Journal of Agricultural Sciene and Technology 17(3):777-787.

Richard Jr EP, Dalley CD (2007) Sugarcane response to bermudagrass interference. Weed Technol. 21(4):941-946.

Schiavetto AR, Perecin D, Azania CAM, Zera FS (2012) Azania and C.M. Lorenzato. Tolerância de cana-de-açúcar a herbicidas avaliada pela diferença dos tratamentos. Planta Daninha. 30(1):173-184

Silva IAB, Kuva MA, Alves PLCA, Salgado TP (2009) Interferência de uma comunidade de plantas daninhas com predominância de Ipomoea hederifolia na cana-soca. Planta Daninha. 27(2):265-272.

Skinner JC (1982) Efficiency of bunch-planted and single-planted seedlings for selecting superior families in sugarcane. Euphytica. 31(2):523-537.

Soares RO, Azania CAM, Lorenzato CM, Schiavetto AR, Zera FS, Azania AAPM (2011) Herbicidas de diferentes mecanismos de ação e a seletividade a cultivares de cana-de-açúcar. Nucleus. 8(1):337-350.

Souza JR, Perecin D, Azania CAM, Schiavetto AR, Pizzo IV, Candido LS (2009) Tolerância de cultivares de cana-de-açúcar a herbicidas aplicados em pós-emergência. Bragantia. 68(4):941-951.

Zera FS, Azania CAM, Schiavetto AR, Lorenzato CM, Azania AAPM (2011) Tolerância de diferentes cultivares de cana-de-açúcar (Saccharum spp.) A herbicidas. Planta Daninha. 29(3):591-599. 